\title{
Perbaikan Proses Produksi Menggunakan ECRS Based Line Balancing pada Lini Perakitan Stator 4
}

\author{
Oksiana Tiovani*) dan Fakhrina Fahma \\ Teknik Industri, Fakultas Teknik, Universitas Sebelas Maret \\ Jl. Ir. Sutami 36A, Surakarta, 57126, Indonesia
}

DOI: 10.20961/performa.18.1.30202

\begin{abstract}
Abstrak
PT. XYZ merupakan salah satu perusahaan manufaktur di Indonesia. Perusahaan tersebut memproduksi pompa air. Komponen penting dalam pompa air adalah stator. Hasil observasi pada lini Perakitan Stator 4 menunjukkan bahwa efisiensi lini yang rendah terjadi karena proses produksi belum berjalan dengan maksimal. Sehingga perbaikan proses produksi penting untuk dilakukan pada lini tersebut. Salah satu metode untuk memperbaiki proses produksi adalah ECRS based line balancing. Dengan tetap mempertimbangkan konsep line balancing, maka efisiensi lini dapat ditingkatkan melalui perbaikan proses produksi. Melalui perbaikan proses produksi, terjadi penurunan jumlah stasiun kerja dari 10 stasiun kerja menjadi 9 stasiun kerja, perbaikan layout lini dan stasiun kerja 7 (Heating Air Dryer) serta peningkatan efisiensi lini dari $74.72 \%$ menjadi $81.09 \%$.
\end{abstract}

Kata kunci: ECRS, proses produksi, keseimbangan lini, perakitan

\begin{abstract}
PT. XYZ is one of the manufacturing companies in Indonesia. The company produces water pumps. An important component in the water pump is the stator. The observation results in the Stator Assembly line 4 show that low line efficiency occurs because the production process has not run optimally. So that an improvement in the production process is important to do on this line. One method to improve the production process is ECRS based line balancing. By still considering the concept of line balancing, line efficiency can be improved through improving the production process. Through the improvement of the production process, there was a decrease in the number of work stations from 10 work stations to 9 work stations, improvement of line layout and 7th work station (Heating Air Dryer), also an increase in line efficiency from $74.72 \%$ to $81.09 \%$.
\end{abstract}

Keywords: ECRS, production process, line balancing, assembly

\section{Pendahuluan}

PT. XYZ merupakan salah satu perusahaan yang bergerak di bidang manufaktur. Perusahaan tersebut memproduksi pompa air. Salah satu komponen penting dalam pompa air adalah stator. Terdapat lima lini Perakitan Stator pada departemen produksi. Penelitian ini berfokus pada lini Perakitan Stator 4. Lini Perakitan Stator 4 merupakan satu-satunya lini perakitan single model di antara lima lini perakitan stator yang terdapat di PT. XYZ dengan pekerja yang memiliki performansi dan skill normal dan merata. Lini ini dilengkapi dengan conveyor untuk membantu perpindahan barang work in process. Berdasarkan hasil observasi yang telah dilakukan, lini tersebut mampu mencapai target produksi. Akan tetapi, efisiensi lini pada lini tersebut terbilang rendah. Hal ini disebabkan oleh proses produksi yang kurang baik yang ditandai dengan distribusi elemen kerja yang dilakukan oleh operator tidak merata dan layout stasiun kerja yang kurang baik. Artikel ini berisi mengenai tahapan-tahapan proses untuk memperbaiki proses produksi pada lini Perakitan Stator 4 menggunakan perbaikan metode kerja ECRS (Eliminate, Combine, Rearrange, Simplify) dengan mempertimbangkan konsep keseimbangan lini. Metode kerja yang lebih baik akan berdampak pada efisiensi dan efektivitas kerja yang akan mengakibatkan berkurangnya waktu pemrosesan (Suhardi, B. dkk., 2019).

Penelitian ini merupakan pengembangan dari penelitian terdahulu. Ongkunaruk dan Wongsatit (2014) pernah melakukan penelitian pada sebuah perusahaan frozen chicken di Thailand dengan menggunakan metode ECRS-based line balancing concept. Dalam penelitian tersebut dilakukan identifikasi operasi bottleneck dan peningkatan kapasitas stasiun untuk meningkatkan kapasitas proses secara keseluruhan. Selain itu, ECRS based line balancing juga digunakan pada penelitian Amran dan Wibowo (2018) mengenai perbaikan proses produksi sistem pengereman dengan ECRS based Line Balancing. Melalui penelitian

*Korespondensi : oksianatiovani@ student.uns.ac.id 
tersebut, Amran dan Wibowo (2018) mampu melakukan pengurangan jumlah operator dan meningkatkan efisiensi lini sehingga biaya produksi berkurang. Sebagai pengembangan dari penelitian sebelumnya, perbaikan proses produksi pada penelitian ini tidak hanya dilakukan dengan perbaikan metode kerja, pendistribusian elemen kerja yang seimbang dan penentuan jumlah stasiun maupun operator. Melainkan turut menyajikan layout lini dan layout stasiun kerja yang baru. Jadi, tujuan penelitian ini adalah memperbaiki proses produksi pada lini Perakitan Stator 4.

\section{Metode Penelitian}

Tahap pertama adalah melakukan perhitungan efisiensi lini sebelum perbaikan dengan menggunakan data waktu siklus tiap elemen kerja. Proses produksi dijabarkan secara rinci dalam elemen-elemen kerja pada setiap stasiun kerja. Kemudian waktu siklus diukur pada setiap elemen kerja. Data waktu siklus didapatkan melalui pengukuran waktu secara langsung dengan menggunakan stopwatch. Perhitungan efisiensi lini sebelum perbaikan didapatkan dengan menggunakan persamaan (3).

Tahap kedua adalah penerapan ECRS based line balancing. Tahapan ini menerapkan metode ECRS dengan tetap mempertimbangkan konsep keseimbangan lini. Amran dan Wibowo (2018) mengungkapkan konsep ECRS berupa metode perbaikan dengan mengeliminasi pekerjaan yang dianggap tidak penting, menggabungkan pekerjaan, mengatur ulang pekerjaan, dan menyederhanakan pekerjaan. Menurut Gaspersz (2004), line balancing merupakan penyeimbangan penugasan elemen-elemen tugas dari suatu assembly line ke work station untuk meminimumkan banyaknya work station dan meminimumkan total idle time pada semua stasiun untuk tingkat output tertentu.

Tahap ketiga adalah perbaikan layout lini dan stasiun kerja. Layout tersebut dibuat berdasarkan usulan perbaikan menggunakan ECRS based line balancing. Jumlah stasiun kerja disesuaikan dengan hasil dari ECRS based line balancing yang telah dilakukan sebelumnya. Perubahan jumlah stasiun kerja akan merubah layout lini Perakitan Stator 4. Adanya elemen kerja baru dari suatu stasiun kerja menyebabkan perlunya perubahan layout stasiun kerja yang bersangkutan.

Tahap keempat adalah perhitungan waktu siklus menggunakan Method Time Measurement-1. Perhitungan ini dilakukan karena perubahan layout menyebabkan perubahan waktu siklus pada elemen kerja yang bersangkutan. Dalam memperoleh nilai waktu siklus tersebut, dilakukan pengukuran waktu tidak langsung. Andriani (2017) mengungkapkan bahwa MTM-1 membagi gerakan-gerakan kerja atas elemenelemen gerakan menjangkau (reach), mengangkut (move), memutar (turn), memegang (grasp), mengarahkan (position), melepas (release), lepas rakit (disassemble), gerakan mata (eye movement), dan beberapa gerakan anggota badan lainnya.

Tahap kelima adalah perhitungan efisiensi lini setelah perbaikan sebagai perbandingan dengan efisiensi lini sebelum perbaikan. Perhitungan efisiensi lini dilakukan dengan menggunakan persamaan (3).

Berikut persamaan matematik yang digunakan dalam penelitian ini:

a. Takt Time

Takt Time adalah waktu yang tersedia untuk memproduksi suatu barang/produk dibagi dengan permintaan dalam periode waktu tertentu (Nabi, F. dkk., 2015).

$$
A_{t t}=C_{T \max }
$$

Dimana :

$A_{t t}=$ Actual Tact Time

$C_{\text {Tmax }}=$ Waktu Siklus Maksimum

b. Efisiensi Stasiun Kerja

Merupakan rasio dari waktu operasi tiap stasiun terhadap waktu siklus atau waktu stasiun kerja terbesar (Marfuah dan Alfiat, 2014).

$$
S_{e}=\frac{T_{i}}{c_{T \max }} \times 100 \%
$$

Dimana :

$S_{e}=$ Efisiensi stasiun kerja

$T_{i}=$ Waktu siklus stasiun kerja ke $-i$

$C_{\text {Tmax }}=$ Waktu Siklus Maksimum

\section{c. Efisiensi Lini}

Efisiensi lini merupakan rasio dari total waktu stasiun kerja dibagi dengan siklus dikalikan jumlah stasiun kerja atau jumlah efisiensi stasiun kerja dibagi jumlah stasiun kerja (Nabi, F. dkk., 2015). 


$$
L_{e}=\frac{\sum_{i=1}^{k} T_{i}}{K \times c_{T \max }} \times 100 \%
$$

Dimana :

$L_{\text {e }}=$ Efisiensi lini

$T_{i}=$ Waktu siklus stasiun kerja ke $-i$

$C_{\text {Tmax }}=$ Waktu Siklus Maksimum

$K=$ Jumlah stasiun kerja yang terdapat dalam lini

\section{Hasil dan Pembahasan}

Bagian ini menjelaskan mengenai hasil dan pembahasan dari tahapan penelitian yang telah dilakukan.

\subsection{Perhitungan Efisiensi Lini Sebelum Perbaikan}

Pada sub bab ini disajikan perhitungan efisiensi lini sebelum perbaikan. Hal ini dilakukan untuk mengetahui keadaan awal lini saat itu. Data waktu siklus setiap elemen kerja yang didapatkan melalui hasil observasi langsung digunakan untuk menghitung efisiensi lini.

Contoh perhitungan actual tact time pada lini Perakitan Stator 4 :

$A_{t t}=C_{T \max }$

$A_{t t}=17,511$ detik.

Contoh perhitungan efisiensi stasiun kerja 9 (Binding-Forming 2) :

$S_{\text {e }}=\frac{T_{9}}{C_{T \max }} \times 100 \%$

$S_{\text {e }}=\frac{10,54}{17,511} \times 100 \%$

$S_{e}=60,19 \%$

Contoh perhitungan efisiensi lini Perakitan Stator 4 :

$L_{i}=\frac{\sum_{i=1}^{k} T_{i}}{K \times C_{T \max }} \times 100 \%$

$L_{\text {e }}=\frac{130,846}{10 \times 17,511} \times 100 \%$

$L_{\text {e }}=74,72 \%$

Hasil perhitungan actual tact time, efisiensi setiap stasiun kerja, dan efisiensi lini Perakitan Stator 4 sebelum perbaikan ditunjukkan pada Tabel 1.

Tabel 1. Rekapitulasi Hasil Perhitungan Efisiensi Lini Sebelum Perbaikan

\begin{tabular}{|c|c|c|c|c|c|c|c|c|c|c|c|c|}
\hline \multicolumn{6}{|c|}{ Nama Lini : Perakitan Stator 4} & \multicolumn{7}{|c|}{ Model : JX 129 AL } \\
\hline \multicolumn{2}{|c|}{ Stasiun Kerja : } & 1 & 2 & 3 & 4 & 5 & 6 & 7 & 8 & 9 & 10 & Total \\
\hline Actual Tact Time & 17.511 & 17.511 & 17.511 & 17.511 & 17.511 & 17.511 & 17.511 & 17.511 & 17.511 & 17.511 & 17.511 & 175.114 \\
\hline Target Tact Time & 22.9 & 22.9 & 22.9 & 22.9 & 22.9 & 22.9 & 22.9 & 22.9 & 22.9 & 22.9 & 22.9 & 229 \\
\hline \multirow{16}{*}{$\begin{array}{c}\text { Waktu Siklus per } \\
\text { Elemen Kerja } \\
\text { (detik) }\end{array}$} & 1 & 0.310 & 0.303 & 1.484 & 0.694 & 0.631 & 0.927 & 0.665 & 0.649 & 3.677 & 4.759 & \\
\hline & 2 & 0.065 & 0.055 & 2.557 & 0.687 & 3.947 & 1.115 & 1.394 & 1.980 & 0.369 & 4.176 & \\
\hline & 3 & 1.133 & 1.113 & 2.888 & 1.942 & 2.775 & 0.249 & 0.800 & 1.678 & 0.198 & 0.713 & \\
\hline & 4 & 0.236 & 0.277 & 1.924 & 1.101 & 0.222 & 0.174 & 0.355 & 0.610 & 3.766 & 0.610 & \\
\hline & 5 & 0.067 & 0.112 & 2.560 & 0.440 & 1.013 & 1.252 & 2.542 & 2.023 & 0.219 & 2.005 & \\
\hline & 6 & 0.153 & 0.200 & 2.929 & 2.133 & 1.970 & 0.183 & 0.281 & 0.297 & 0.199 & & \\
\hline & 7 & 1.149 & 1.705 & 0.685 & 1.306 & 0.196 & 0.167 & 0.574 & 3.999 & 0.594 & & \\
\hline & 8 & 0.065 & 0.058 & 0.285 & 0.271 & 1.971 & 0.339 & 1.694 & 0.642 & 0.188 & & \\
\hline & 9 & 0.135 & 0.224 & 0.988 & 0.616 & 0.290 & 0.168 & 0.333 & & 1.331 & & \\
\hline & 10 & 0.222 & 0.270 & 0.307 & 1.267 & 2.139 & 1.476 & 0.975 & & & & \\
\hline & 11 & 0.403 & 0.402 & 0.170 & 0.230 & 0.185 & 0.333 & 0.763 & & & & \\
\hline & 12 & 3.414 & 3.408 & 0.735 & 0.873 & 0.880 & 0.258 & 1.029 & & & & \\
\hline & 13 & 0.184 & 0.293 & & & & 1.154 & 0.746 & & & & \\
\hline & 14 & 0.363 & 0.379 & & & & & 0.523 & & & & \\
\hline & 15 & 4.696 & 5.408 & & & & & & & & & \\
\hline & 16 & 1.779 & 1.831 & & & & & & & & & \\
\hline \multicolumn{2}{|c|}{ Total Waktu Siklus : } & 14.372 & 16.038 & 17.511 & 11.561 & 16.219 & 7.795 & 12.673 & 11.877 & 10.540 & 12.262 & 130.846 \\
\hline \multicolumn{2}{|c|}{ Nama Stasiun : } & $\begin{array}{c}\text { Main } \\
\text { Coil } \\
\text { Winding }\end{array}$ & $\begin{array}{l}\text { Sub Coil } \\
\text { Winding }\end{array}$ & Coil Insert & $\begin{array}{c}\text { Forming } \\
1\end{array}$ & Lacing & $\begin{array}{c}\text { Caulking- } \\
\text { Dipping }\end{array}$ & $\begin{array}{l}\text { Heating } \\
\text { Air } \\
\text { Dryer }\end{array}$ & $\begin{array}{c}\text { Insulation } \\
\text { Tube }\end{array}$ & $\begin{array}{l}\text { Binding- } \\
\text { Forming } \\
\quad 2\end{array}$ & Inspection & \\
\hline \multicolumn{2}{|c|}{ Efisiensi Lini : } & $82.07 \%$ & $91.58 \%$ & $100.00 \%$ & $66.02 \%$ & $92.62 \%$ & $44.51 \%$ & $72.37 \%$ & $67.82 \%$ & $60.19 \%$ & $70.02 \%$ & $74.72 \%$ \\
\hline
\end{tabular}


Berdasarkan Tabel 1, terlihat bahwa actual tact time sebesar 17,511 detik, nilai efisiensi stasiun kerja yang variatif, serta efisiensi lini sebesar $74,72 \%$.

Tingkat keseimbangan lini Perakitan Stator 4 sebelum perbaikan diperjelas pada Gambar 1.

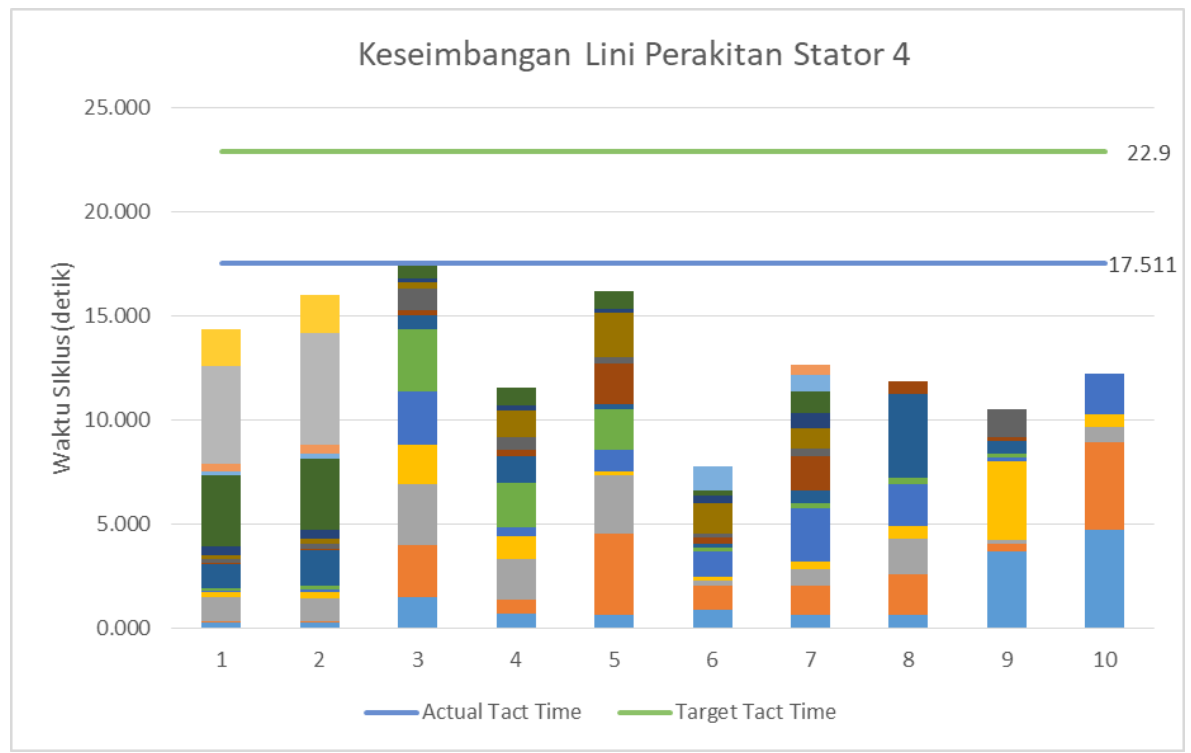

Gambar 1. Grafik Keseimbangan Lini Perakitan Stator 4 Sebelum Perbaikan

Berdasarkan Gambar 1, ditunjukkan kondisi keseimbangan lini Perakitan Stator 4 dimana pendistribusian elemen kerja belum merata.

\subsection{Penerapan ECRS}

Pada sub bab ini disajikan penerapan perbaikan metode kerja menggunakan ECRS (Eliminate, Combine, Rearrange, Simplify) sebagai salah satu tahap awal untuk perbaikan proses produksi. Dalam penerapan ini, keseimbangan lini menjadi salah satu konsep yang dipegang. Hal ini dilakukan agar metode kerja yang baru dapat mempertahankan bahkan meningkatkan efisiensi lini Perakitan Stator 4.

Perbaikan metode kerja (ECRS) dilakukan mulai dari stasiun 7 (Heating Air Dryer) sampai dengan stasiun 10 (Inspection). Perbaikan dimulai dari stasiun 7 (Heating Air Dryer) karena stasiun 1 (Main Coil Winding) sampai dengan stasiun 5 (Lacing) menggunakan mesin-mesin yang bekerja secara individual. Sedangkan pada stasiun 6 (Caulking-Dipping) terdapat waktu tunggu selama 5 menit untuk pengeringan sebelum diproses pada stasiun 7 (Heating Air Dryer) sehingga harus bekerja lebih cepat dari stasiun lain untuk menyediakan barang work in process (WIP) agar produksi dapat terus berjalan. Dalam pendistribusian elemen tugas, konsep keseimbangan lini dijadikan pegangan agar beban kerja setiap stasiun merata. Setelah digunakan ECRS based line balancing, terjadi pengurangan jumlah stasiun kerja. Dimana elemen kerja pada stasiun 8 (Insulation Tube) didistribusikan ke stasiun kerja lain sehingga stasiun 8 (Insulation Tube) dapat dihilangkan.

Perbaikan metode kerja (ECRS) yang dibuat dengan mempertimbangkan keseimbangan lini ditunjukkan pada Gambar 2. 


\begin{tabular}{|c|c|c|}
\hline \multicolumn{3}{|c|}{ BEFORE IMPROVEMENT } \\
\hline \multirow[b]{2}{*}{ No } & \multicolumn{2}{|l|}{ Stasiun 7 (Heating Air Dryer) } \\
\hline & Elemen Kerja & $\begin{array}{l}\text { Waktu } \\
\text { Proses }\end{array}$ \\
\hline 1 & Mengambil stator dari conveyor & 0.665 \\
\hline 2 & Mengambil 3 heat shrink & 1.394 \\
\hline 3 & $\begin{array}{c}\text { Memasukkan ketiga ujung lead wire } \\
\text { ke dalam heat shrink }\end{array}$ & 0.800 \\
\hline 4 & Memasukkan lead wire ke mesin & 0.355 \\
\hline 5 & $\begin{array}{l}\text { Menunggu (mengambil dan } \\
\text { memasukkan insulation tube pendek } \\
\text { dan panjang, meletakkan stator ke } \\
\text { conveyor) }\end{array}$ & 4.035 \\
\hline 6 & $\begin{array}{l}\text { Memeriksa dan mengeluarkan lead } \\
\text { wire dari mesin }\end{array}$ & 2.542 \\
\hline 7 & $\begin{array}{c}\text { Meletakkan stator berdekatan } \\
\text { dengan conveyor }\end{array}$ & 0.281 \\
\hline 8 & Mengambil penjepit & 0.574 \\
\hline 9 & Menjepit heat shrink & 1.694 \\
\hline 10 & Meletakkan penjepit & 0.333 \\
\hline 11 & $\begin{array}{l}\text { Mendinginkan heat shrink } \\
\text { (mengambil stator dari conveyer, } \\
\text { mengambil dan memasang heat } \\
\text { shrink, memanaskan lead wire) }\end{array}$ & 3.215 \\
\hline 12 & Mengambil insulation tube pendek & 0.975 \\
\hline 13 & $\begin{array}{l}\text { Memasukkan insulation tube pendek } \\
\text { ke thermal protector pendek }\end{array}$ & 0.763 \\
\hline 14 & Mengambil insulation tube panjang & 1.029 \\
\hline 15 & $\begin{array}{c}\text { Memasukkan insulation tube panjang } \\
\text { ke thermal protector panjang }\end{array}$ & 0.746 \\
\hline 16 & Meletakkan stator ke conveyor & 0.523 \\
\hline & Total Waktu Siklus : & 12.673 \\
\hline
\end{tabular}

\begin{tabular}{|c|c|c|c|}
\hline & \multicolumn{3}{|c|}{ AFTER IMPROVEMENT } \\
\hline & \multirow[b]{2}{*}{ No } & \multicolumn{2}{|l|}{ Stasiun 7 (Heating Air Dryer) } \\
\hline & & Elemen Kerja & $\begin{array}{l}\text { Waktu } \\
\text { Proses }\end{array}$ \\
\hline & 1 & Mengambil stator dari conveyor & 1.132 \\
\hline & 2 & Mengambil 3 heat shrink & 0.706 \\
\hline & 3 & $\begin{array}{l}\text { Memasukkan ketiga ujung lead wire } \\
\text { ke dalam heat shrink }\end{array}$ & 0.800 \\
\hline & 4 & Memasukkan lead wire ke mesin & 0.355 \\
\hline \multirow[t]{5}{*}{1} & 5 & Mengeluarkan lead wire dari mesin & 0.187 \\
\hline & 6 & $\begin{array}{c}\text { Meletakkan stator berdekatan } \\
\text { dengan conveyor }\end{array}$ & 0.415 \\
\hline & 7 & Mengambil penjepit & 0.630 \\
\hline & 8 & Menjepit heat shrink & 1.694 \\
\hline & 9 & Meletakkan penjepit & 0.392 \\
\hline \multirow[t]{2}{*}{2} & 10 & $\begin{array}{l}\text { Mengambil insulation tube pendek } \\
\text { dan panjang }\end{array}$ & 1.177 \\
\hline & 11 & $\begin{array}{l}\text { Memasukkan insulation tube pendek } \\
\text { ke thermal protector pendek }\end{array}$ & 0.763 \\
\hline 3 & 12 & $\begin{array}{c}\text { Memasukkan insulation tube panjang } \\
\text { ke thermal protector panjang }\end{array}$ & 0.746 \\
\hline 4 & 13 & Mengambil 2 insulation tube & 0.677 \\
\hline 5 & 14 & $\begin{array}{l}\text { Memasukkan } 2 \text { insulation tube ke } \\
\text { bagian lead wire merah dan putih }\end{array}$ & 1.980 \\
\hline 6 & 15 & $\begin{array}{l}\text { Merapikan lead wire dan thermal } \\
\text { protector }\end{array}$ & 1.678 \\
\hline 7 & 16 & Mengambil cable tie & 0.677 \\
\hline 8 & 17 & $\begin{array}{l}\text { Mengikat lead wire dan thermal } \\
\text { protector dengan cable tie }\end{array}$ & 2.023 \\
\hline \multirow[t]{2}{*}{9} & 18 & Meletakkan stator ke conveyor & 0.826 \\
\hline & & Total Waktu Siklus : & 16.857 \\
\hline
\end{tabular}

Gambar 2. Penerapan ECRS pada Lini Perakitan Stator 4 


\begin{tabular}{|c|c|c|c|}
\hline \multicolumn{3}{|c|}{ BEF ORE IMPROVEMENT } & \\
\hline \multirow[b]{2}{*}{ No } & \multicolumn{2}{|l|}{ Stasiun 8 (Insulation Tube) } & \\
\hline & Elemen Kerja & $\begin{array}{l}\text { Waktu } \\
\text { Proses }\end{array}$ & \\
\hline 1 & Mengambil 2 insulation tube & 0.649 & 4 \\
\hline 2 & $\begin{array}{l}\text { Memasukkan } 2 \text { insulation tube ke } \\
\text { bagian lead wire merah dan putih }\end{array}$ & 1.980 & 5 \\
\hline 3 & $\begin{array}{l}\text { Merapikan lead wire dan thermal } \\
\text { protector }\end{array}$ & 1.678 & 6 \\
\hline 4 & Mengambil cable tie & 0.610 & 7 \\
\hline 5 & $\begin{array}{l}\text { Mengik at lead wire dan thermal } \\
\text { protector dengan cable tie }\end{array}$ & 2.023 & 8 \\
\hline 6 & Mengambil benang & 0.297 & 10 \\
\hline 7 & $\begin{array}{l}\text { Mengikat lead wire dan thermal } \\
\text { protector dengan benang }\end{array}$ & 3.999 & 11 \\
\hline 8 & $\begin{array}{l}\text { Menggunting benang dan cable tie } \\
\text { serta membuang sisa pengguntingan }\end{array}$ & 0.642 & 12 \\
\hline & Total Waktu Siklus & 11.877 & \\
\hline
\end{tabular}

\begin{tabular}{|c|c|l|}
\hline \multicolumn{2}{|c|}{ AFTER IMPROVEMENT } \\
\hline \multirow{2}{*}{ No } & \multicolumn{2}{|c|}{ Stasiun - } \\
\cline { 2 - 3 } & Elemen Kerja & Waktu Proses \\
\hline \multicolumn{2}{|c|}{ Penghilangan Stasiun Kerja } \\
\hline
\end{tabular}

\begin{tabular}{|c|c|c|c|}
\hline \multicolumn{3}{|c|}{ BEFORE IMPROVEMENT } & \\
\hline \multirow[b]{2}{*}{ No } & \multicolumn{2}{|l|}{ Stasiun 9 (Binding-Forming 2) } & \\
\hline & Elemen Kerja & \begin{tabular}{|l|} 
Waktu \\
Proses
\end{tabular} & \\
\hline 1 & Mengikat thermal protector 1 & 3.6772 & 13 \\
\hline 2 & Menggunting sisa benang & 0.3687 & 14 \\
\hline 3 & Membuang sisa benang & 0.198 & 15 \\
\hline 4 & Mengikat thermal protector 2 & 3.7662 & 16 \\
\hline 5 & Menggunting sisa benang & 0.2187 & 17 \\
\hline 6 & Membuang sisa benang & 0.1985 & 18 \\
\hline 7 & Meletakkan stator ke mesin & 0.5937 & 19 \\
\hline 8 & Menekan double switch & 0.188 & 20 \\
\hline 9 & $\begin{array}{c}\text { Meletakkan stator ke conveyor dan } \\
\text { memeriksa stator }\end{array}$ & 1.3308 & 21 \\
\hline & Total Waktu Siklus : & 10.54 & \\
\hline
\end{tabular}

\begin{tabular}{|c|c|c|c|}
\hline & \multicolumn{3}{|c|}{ AFTER IMPROVEMENT } \\
\hline & \multirow[b]{2}{*}{ No } & \multicolumn{2}{|l|}{ Stasiun 8 (Binding-Forming 2) } \\
\hline & & Elemen Kerja & $\begin{array}{l}\text { Waktu } \\
\text { Proses }\end{array}$ \\
\hline 11 & 1 & $\begin{array}{l}\text { Mengikat lead wire dan thermal } \\
\text { protector dengan benang }\end{array}$ & 3.999 \\
\hline 12 & 2 & $\begin{array}{l}\text { Menggunting benang dan cable tie } \\
\text { serta membuang sisa pengguntingan }\end{array}$ & 0.642 \\
\hline 13 & 3 & Mengikat thermal protector 1 & 3.677 \\
\hline 14 & 4 & Menggunting sisa benang & 0.369 \\
\hline 15 & 5 & Membuang sisa benang & 0.198 \\
\hline 16 & 6 & Mengikat thermal protector 2 & 3.766 \\
\hline 17 & 7 & Menggunting sisa benang & 0.219 \\
\hline 18 & 8 & Membuang sisa benang & 0.199 \\
\hline 19 & 9 & Meletakkan stator ke mesin & 0.594 \\
\hline 20 & 10 & Menekan double switch & 0.188 \\
\hline 21 & 11 & $\begin{array}{l}\text { Meletakkan stator ke conveyor dan } \\
\text { memeriksa stator }\end{array}$ & 1.331 \\
\hline & & Total Waktu Siklus : & 15.180 \\
\hline
\end{tabular}

Gambar 2. Penerapan ECRS pada Lini Perakitan Stator 4 (lanjutan) 


\begin{tabular}{|c|c|c|}
\hline \multicolumn{3}{|c|}{ BEFORE IMPROVEMENT } \\
\hline \multirow[b]{2}{*}{ No } & \multicolumn{2}{|l|}{ Stasiun 10 (Inspection) } \\
\hline & Elemen Kerja & $\begin{array}{l}\text { Waktu } \\
\text { Proses }\end{array}$ \\
\hline 1 & $\begin{array}{c}\text { Meletakkan stator ke mesin dan } \\
\text { membuang selaput kabel }\end{array}$ & 4.759 \\
\hline 2 & Menyambungkan kabel & 4.176 \\
\hline 3 & Menutup cover mesin & 0.713 \\
\hline 4 & $\begin{array}{c}\text { Menunggu (melakukan proses pada } \\
\text { mesin lain) }\end{array}$ & 12.262 \\
\hline 5 & Membuka cover mesin & 0.610 \\
\hline 6 & $\begin{array}{l}\text { Memeriksa dan meletakkan stator } \\
\text { ke rak vanish }\end{array}$ & 2.005 \\
\hline & Total Waktu Siklus : & 12.262 \\
\hline
\end{tabular}

\begin{tabular}{|c|c|c|c|}
\hline & \multicolumn{3}{|c|}{ AFTER IMPROVEMENT } \\
\hline & \multirow[b]{2}{*}{ No } & \multicolumn{2}{|l|}{ Stasiun 9 (Inspection) } \\
\hline & & Elemen Kerja & $\begin{array}{l}\text { Waktu } \\
\text { Proses }\end{array}$ \\
\hline 22 & 1 & $\begin{array}{c}\text { Meletakkan stator ke mesin dan } \\
\text { membuang selaput kabel }\end{array}$ & 4.759 \\
\hline 23 & 2 & Menyambungkan kabel & 4.176 \\
\hline 24 & 3 & Menutup cover mesin & 0.713 \\
\hline 25 & 4 & Membuka cover mesin & 0.610 \\
\hline \multirow[t]{2}{*}{26} & 5 & $\begin{array}{c}\text { Memeriksa dan meletakkan stator ke } \\
\text { rak vanish }\end{array}$ & 2.005 \\
\hline & & Total Waktu Siklus : & 12.262 \\
\hline
\end{tabular}

Keterangan :

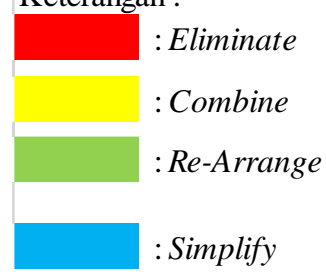

Gambar 2. Penerapan ECRS pada Lini Perakitan Stator 4 (lanjutan)

Berdasarkan Gambar 2, ditunjukkan perubahan elemen kerja yang terlibat dalam proses produksi. Perubahan ini terjadi sebagai upaya perbaikan menggunakan ECRS based line balancing.

\subsection{Perubahan Layout Lini Perakitan Stator 4}

Pada sub bab ini disajikan perubahan layout lini Perakitan Stator 4. Layout awal dan layout usulan perbaikan lini Perakitan Stator 4 ditunjukkan pada Gambar 3.



Gambar 3. Perubahan Layout Lini Perakitan Stator 4

Berdasarkan Gambar 3, ditunjukkan bahwa terdapat pengurangan jumlah stasiun kerja. Layout awal lini Perakitan Stator 4 terdiri dari 10 stasiun kerja yang meliputi Main Coil Winding, Sub Coil Winding, Coil Insert, Forming 1, Lacing, Caulking-Dipping, Heating Air Dryer, Insulation Tube, Binding-Forming 2, dan Inspection. Setelah dilakukan perubahan dengan metode ECRS dan konsep keseimbangan lini, maka dapat dilakukan penghilangan stasiun kerja 8 (Insulation Tube). Akibat hilangnya stasiun 8 (Insulation Tube) maka layout baru lini Perakitan Stator 4 hanya memuat 9 stasiun yang meliputi Main Coil Winding, Sub Coil Winding, Coil Insert, Forming 1, Lacing, Caulking-Dipping, Heating Air Dryer, Binding-Forming 2, dan Inspection. Operator pada stasiun Heating Air Dryer dan Binding-Forming 2 tetap menggunakan orang yang 
sama meskipun terjadi penambahan elemen kerja. Sedangkan operator pada stasiun 8 (Insulation Tube) dikeluarkan karena stasiun tersebut dihilangkan.

\subsection{Perubahan Layout Stasiun Kerja 7}

Pada sub bab ini disajikan perubahan layout stasiun kerja 7. Perubahan layout stasiun kerja 7 terjadi akibat penghilangan stasiun 8 (Insulation Tube) sehingga pengikatan lead wire dan thermal protector dengan cable tie dilakukan pada stasiun 7 (Heating Air Dryer). Layout awal stasiun kerja 7 (Heating Air Dryer) ditunjukkan pada Gambar 4.

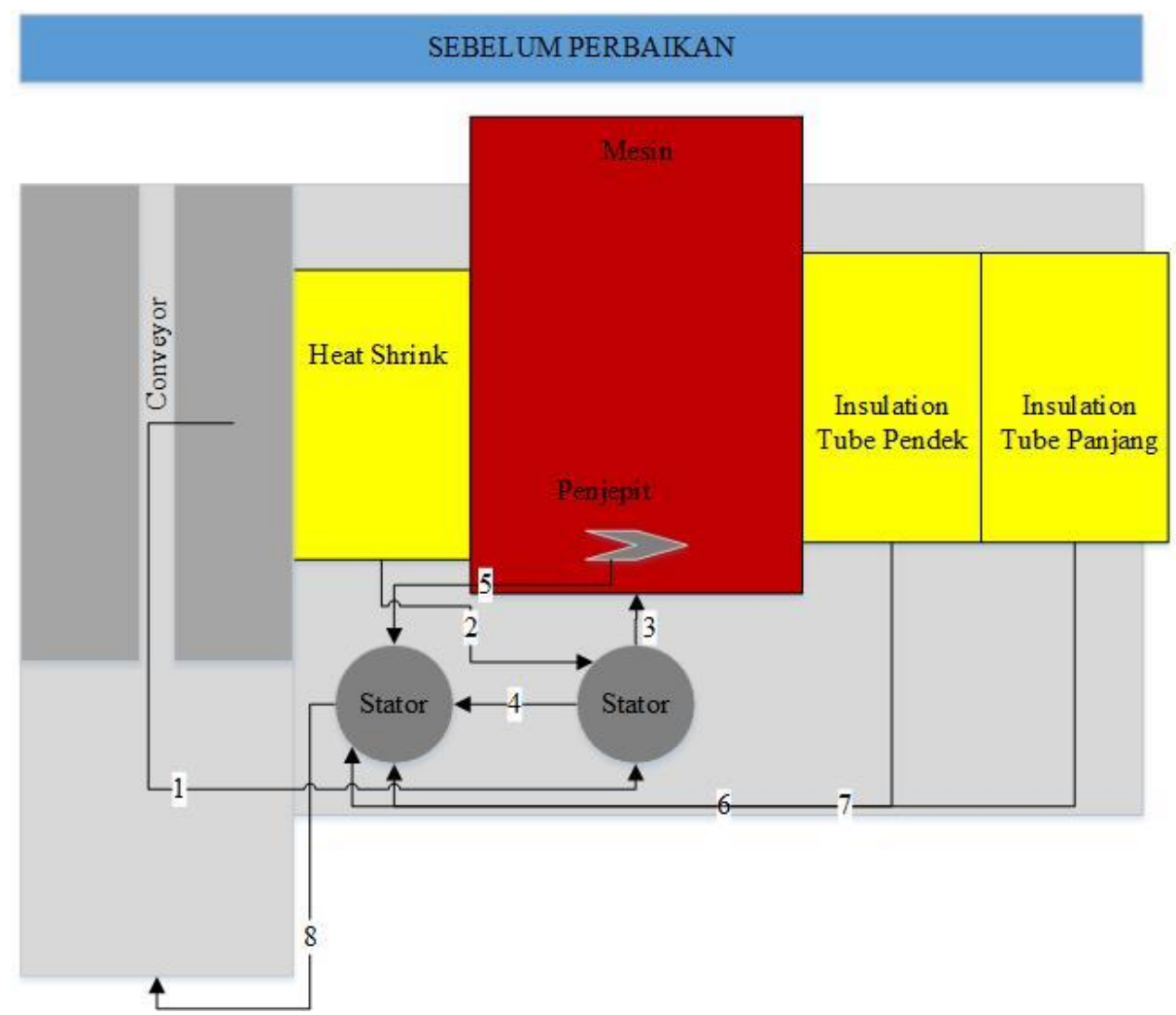

Gambar 4. Layout Awal Stasiun Kerja 7

Berdasarkan Gambar 4, diketahui 4 objek utama yang diletakkan di meja yaitu pallet heat shrink, mesin, penjepit, dan pallet insulation tube. Meja tersebut diletakkan tepat di samping conveyor. Layout awal stasiun kerja 7 (Heating Air Dryer) tidak efektif karena jarak pallet insulation tube yang jauh.

Layout usulan stasiun kerja 7 (Heating Air Dryer) ditunjukkan pada Gambar 5.

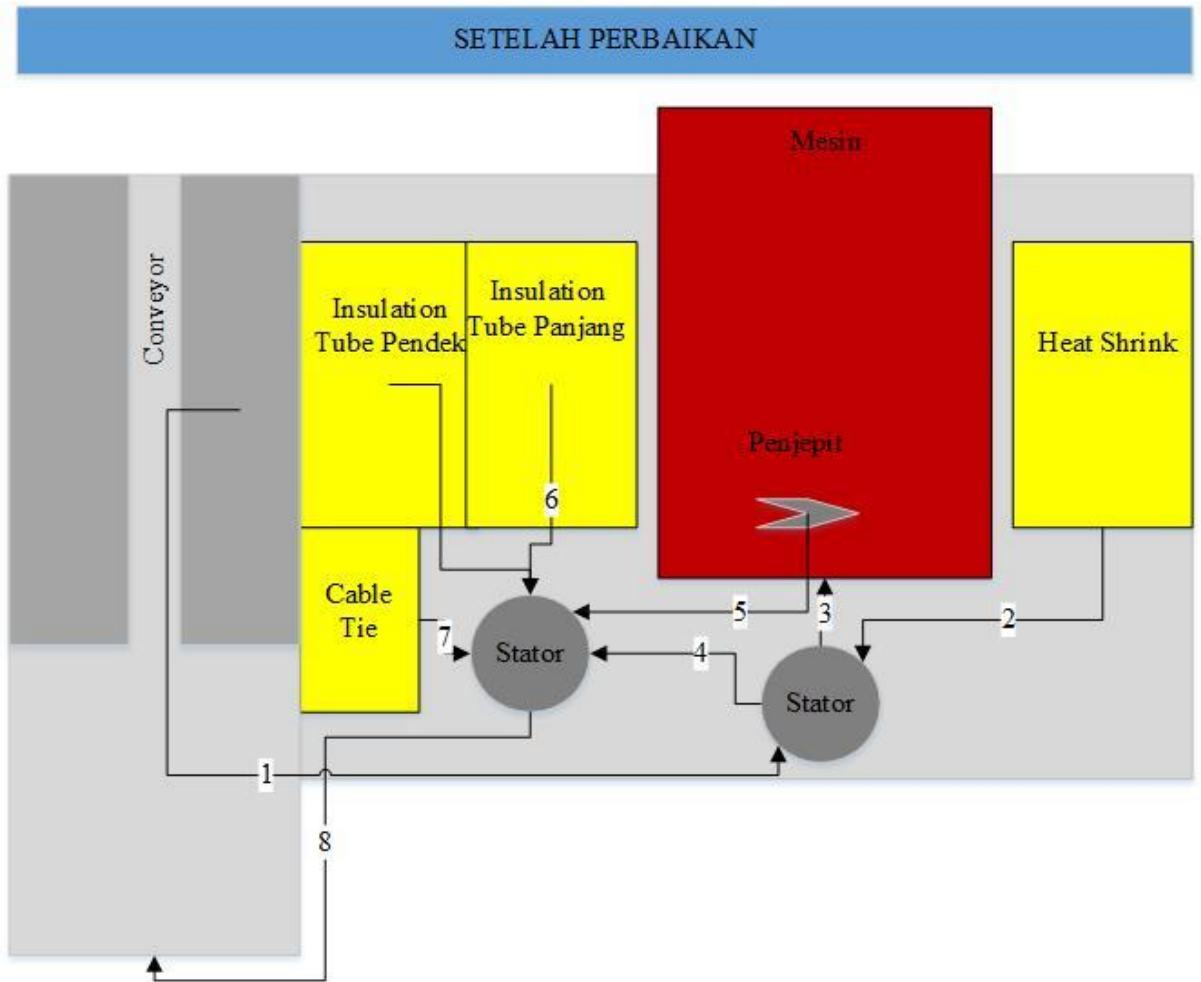

Gambar 5. Layout Usulan Perbaikan Stasiun Kerja 7 
Berdasarkan Gambar 5, ditunjukkan perubahan dengan menukar posisi pallet insulation tube dengan pallet heat shrink untuk memperpendek jarak perpindahan. Selain perubahan tersebut, dilakukan penambahan pallet cable tie. Akibat penambahan pallet, dilakukan perubahan ukuran meja yang semula berukuran 70 x 50 $\mathrm{cm}$ menjadi $80 \times 50 \mathrm{~cm}$. Perubahan ini dapat dilakukan karena terdapat beberapa meja yang dapat ditukar fungsinya. Seperti meja yang digunakan untuk meletakkan part reject dapat ditukar dengan meja perakitan lini Stator Assembly 4. Penggunaan meja berukuran 80 x $50 \mathrm{~cm}$ telah diterapkan pada beberapa lini lain untuk stasiun Heating Air Dryer.

\subsection{Perhitungan Waktu Siklus Menggunakan MTM-1}

Pada sub bab ini disajikan perhitungan waktu siklus menggunakan Methods Time Measurement-1.

Setelah dilakukan perbaikan layout pada stasiun kerja 7 (Heating Air Dryer) maka diperlukan perhitungan waktu kerja yang baru. Pada penelitian ini, digunakan metode pengukuran waktu kerja tidak langsung yaitu Method Time Measurement-1.

Perubahan layout yang dilakukan adalah penukaran posisi pallet insulation tube dan heat shrink. Selain itu, terdapat penambahan pallet cable tie. Akibat dari perubahan layout stasun kerja 7 (Heating Air Dryer) maka beberapa elemen kerja mengalami perubahan waktu proses. Elemen kerja yang mengalami perubahan waktu proses meliputi elemen kerja $1,2,5,6,7,9,10,13,16$, dan 18 dengan hasil perhitungan waktu munggunakan MTM-1 secara berurutan meliputi 1,132 detik, 0,706 detik, 0,187 detik, 0,415 detik, 0,630 detik, 0,392 detik, 1,177 detik, 0,677 detik, 0,677 detik, 0,826 detik. Elemen-elemen kerja tersebut memiliki waktu proses yang berbeda karena jarak perpindahan obyek mengalami perubahan. Dalam menentukan kodekode MTM-1 yang tepat, dilakukan pengukuran jarak melalui observasi langsung dan penimbangan massa stator.

Hasil perhitungan waktu proses baru pada stasiun kerja 7 ditunjukkan pada Tabel 2.

Tabel 2. Methods Time Measumement-1 pada Stasiun 7

\begin{tabular}{|c|c|c|c|c|c|}
\hline \multicolumn{6}{|c|}{ Methods Time Measurement -1 Setelah Perbaikan untuk Stasiun 7} \\
\hline $\begin{array}{c}\text { No } \\
\text { Proses }\end{array}$ & Code & TMU & TMU & Code & $\begin{array}{c}\text { Waktu Proses } \\
\text { (detik) }\end{array}$ \\
\hline \multirow{3}{*}{1} & $\mathrm{R} 14 \mathrm{~A}$ & 10.5 & 0 & - & \\
\hline & M16Bm3.48 & 18.948 & 0 & - & \\
\hline & RL1 & 2 & 0 & - & \\
\hline \multicolumn{2}{|c|}{ Total TMU Elemen Kerja 1 : } & \multicolumn{2}{|c|}{31.448} & x 0.036 & 1.132 \\
\hline \multirow{3}{*}{2} & G5 & 0 & 6.4 & R4B & \\
\hline & G5 & 0 & 3.5 & G1B & \\
\hline & G5 & 0 & 9.7 & M7B & \\
\hline \multicolumn{2}{|c|}{ Total TMU Elemen Kerja 2 : } & \multicolumn{2}{|c|}{19.6} & x 0.036 & 0.706 \\
\hline 3 & \multicolumn{4}{|c|}{ Waktu Proses : } & 0.800 \\
\hline 4 & \multicolumn{4}{|c|}{ Waktu Proses : } & 0.355 \\
\hline 5 & G5 & 0 & 5.2 & M2C & \\
\hline \multicolumn{2}{|c|}{ Total TMU Elemen Kerja 5 : } & \multicolumn{2}{|c|}{5.2} & x 0.036 & 0.187 \\
\hline \multirow{2}{*}{6} & M4Bm3.48 & 9.514 & 0 & - & \\
\hline & RL1 & 2 & 0 & - & \\
\hline \multicolumn{2}{|c|}{ Total TMU Elemen Kerja 6 : } & \multicolumn{2}{|c|}{11.514} & x 0.036 & 0.415 \\
\hline \multirow{2}{*}{7} & G5 & 0 & 8.6 & R6B & \\
\hline & G5 & 0 & 8.9 & M6B & \\
\hline \multicolumn{2}{|c|}{ Total TMU Elemen Kerja 7 : } & \multicolumn{2}{|c|}{17.5} & x 0.036 & 0.630 \\
\hline 8 & & \multicolumn{3}{|c|}{ Waktu Proses : } & 1.694 \\
\hline \multirow{2}{*}{9} & - & 0 & 8.9 & M6B & \\
\hline & - & 0 & 2 & RL1 & \\
\hline \multicolumn{2}{|c|}{ Total TMU Elemen Kerja 9 : } & \multicolumn{2}{|c|}{10.9} & x 0.036 & 0.392 \\
\hline
\end{tabular}


Tabel 2. Methods Time Measumement-1 pada Stasiun 7 (Lanjutan)

\begin{tabular}{|c|c|c|c|c|c|}
\hline $\begin{array}{c}\text { No } \\
\text { Proses }\end{array}$ & Code & TMU & TMU & Code & $\begin{array}{c}\text { Waktu Proses } \\
\text { (detik) }\end{array}$ \\
\hline \multirow{5}{*}{10} & G5 & 0 & 10.8 & R7D & \\
\hline & G5 & 0 & 3.5 & G1B & \\
\hline & G5 & 0 & 6.9 & M4B & \\
\hline & G5 & 0 & 3.5 & G1B & \\
\hline & G5 & 0 & 8 & M5B & \\
\hline \multicolumn{2}{|c|}{ Total TMU Elemen Kerja 10 : } & \multicolumn{2}{|c|}{32.7} & x 0.036 & 1.177 \\
\hline 11 & \multicolumn{4}{|c|}{ Waktu Proses : } & 0.763 \\
\hline 12 & \multicolumn{4}{|c|}{ Waktu Proses : } & 0.746 \\
\hline \multirow{3}{*}{13} & G5 & 0 & 8.4 & R4D & \\
\hline & G5 & 0 & 3.5 & G1B & \\
\hline & G5 & 0 & 6.9 & M4B & \\
\hline \multicolumn{2}{|c|}{ Total TMU Elemen Kerja 13 : } & \multicolumn{2}{|c|}{18.8} & $\mathrm{x} 0.036$ & 0.677 \\
\hline 14 & \multicolumn{4}{|c|}{ Waktu Proses : } & 1.980 \\
\hline 15 & \multicolumn{4}{|c|}{ Waktu Proses : } & 1.678 \\
\hline \multirow{3}{*}{16} & G5 & 0 & 8.4 & $\mathrm{R} 4 \mathrm{D}$ & \\
\hline & G5 & 0 & 3.5 & G1B & \\
\hline & G5 & 0 & 6.9 & M4B & \\
\hline \multicolumn{2}{|c|}{ Total TMU Elemen Kerja 16 : } & \multicolumn{2}{|c|}{18.8} & $\mathrm{x} 0.036$ & 0.677 \\
\hline 17 & \multicolumn{4}{|c|}{ Waktu Proses : } & 2.023 \\
\hline \multirow{3}{*}{18} & G1A & 2 & 0 & - & \\
\hline & M16Bm3.48 & 18.948 & 0 & - & \\
\hline & RL1 & 2 & 0 & - & \\
\hline \multicolumn{2}{|c|}{ Total TMU Elemen Kerja 18 : } & \multicolumn{2}{|c|}{22.948} & x 0.036 & 0.826 \\
\hline
\end{tabular}

Berdasarkan Tabel 2, ditunjukkan bahwa beberapa proses mengalami perubahan waktu proses. Proses yang memerlukan perhitungan TMU merupakan proses yang mengalami perubahan waktu proses, berlaku sebaliknya. Kode bagian kiri tabel merupakan kode untuk gerakan yang dilakukan oleh tangan kiri. Sedangkan kode bagian kanan tabel merupakan kode untuk gerakan yang dilakukan oleh tangan kanan. Kodekode tersebut dibuat berdasarkan tabel MTM-1.

\subsection{Perhitungan Efisiensi Lini Setelah Perbaikan}

Pada sub bab ini disajikan perhitungan efisiensi lini setelah perbaikan. Hal ini dilakukan untuk mengetahui pengaruh perbaikan proses produksi terhadap efisiensi lini Perakitan Stator 4.

Contoh perhitungan actual tact time pada lini Perakitan Stator 4 :

$A_{t t}=C_{T \max }$

$A_{t t}=17,511$ detik.

Contoh perhitungan efisiensi stasiun kerja 8 (Binding-Forming 2) :

$S_{e}=\frac{T_{8}}{C_{T \max }} \times 100 \%$

$S_{e}=\frac{15,18}{17,511} \times 100 \%$

$S_{e}=86,69 \%$

Contoh perhitungan efisiensi lini Perakitan Stator 4 :

$L_{\theta}=\frac{\sum_{i=1}^{k} T_{i}}{K \times C_{T \max }} \times 100 \%$

$L_{\theta}=\frac{127,794}{9 \times 17,511} \times 100 \%$ 
Hasil perhitungan actual tact time, efisiensi setiap stasiun kerja, dan efisiensi lini Perakitan Stator 4 setelah perbaikan ditunjukkan pada Tabel 3 .

Tabel 3. Rekapitulasi Hasil Perhitungan Efisiensi Lini Setelah Perbaikan

\begin{tabular}{|c|c|c|c|c|c|c|c|c|c|c|c|}
\hline \multicolumn{6}{|c|}{ Nama Lini : Perakitan Stator 4} & \multicolumn{6}{|c|}{ Model : JX 129 AL } \\
\hline \multicolumn{2}{|c|}{ Stasiun Kerja : } & 1 & 2 & 3 & 4 & 5 & 6 & 7 & 8 & 9 & Total \\
\hline Actual Tact Time & 17.511 & 17.511 & 17.511 & 17.511 & 17.511 & $\mathbf{1 7 . 5 1 1}$ & 17.511 & 17.511 & 17.511 & 17.511 & 157.603 \\
\hline Target Tact Time & 22.9 & 22.9 & 22.9 & 22.9 & 22.9 & 22.9 & 22.9 & 22.9 & 22.9 & 22.9 & 229 \\
\hline \multirow{18}{*}{$\begin{array}{c}\text { Waktu Siklus per } \\
\text { Elemen Kerja (detik) }\end{array}$} & 1 & 0.310 & 0.303 & 1.484 & 0.694 & 0.631 & 0.927 & 1.132 & 3.999 & 4.759 & \\
\hline & 2 & 0.065 & 0.055 & 2.557 & 0.687 & 3.947 & 1.115 & 0.706 & 0.642 & 4.176 & \\
\hline & 3 & 1.133 & 1.113 & 2.888 & 1.942 & 2.775 & 0.249 & 0.800 & 3.677 & 0.713 & \\
\hline & 4 & 0.236 & 0.277 & 1.924 & 1.101 & 0.222 & 0.174 & 0.355 & 0.369 & 0.610 & \\
\hline & 5 & 0.067 & 0.112 & 2.560 & 0.440 & 1.013 & 1.252 & 0.187 & 0.198 & 2.005 & \\
\hline & 6 & 0.153 & 0.200 & 2.929 & 2.133 & 1.970 & 0.183 & 0.415 & 3.766 & & \\
\hline & 7 & 1.149 & 1.705 & 0.685 & 1.306 & 0.196 & 0.167 & 0.630 & 0.219 & & \\
\hline & 8 & 0.065 & 0.058 & 0.285 & 0.271 & 1.971 & 0.339 & 1.694 & 0.199 & & \\
\hline & 9 & 0.135 & 0.224 & 0.988 & 0.616 & 0.290 & 0.168 & 0.392 & 0.594 & & \\
\hline & 10 & 0.222 & 0.270 & 0.307 & 1.267 & 2.139 & 1.476 & 1.177 & 0.188 & & \\
\hline & 11 & 0.403 & 0.402 & 0.170 & 0.230 & 0.185 & 0.333 & 0.763 & 1.331 & & \\
\hline & 12 & 3.414 & 3.408 & 0.735 & 0.873 & 0.880 & 0.258 & 0.746 & & & \\
\hline & 13 & 0.184 & 0.293 & & & & 1.154 & 0.677 & & & \\
\hline & 14 & 0.363 & 0.379 & & & & & 1.980 & & & \\
\hline & 15 & 4.696 & 5.408 & & & & & 1.678 & & & \\
\hline & 16 & 1.779 & 1.831 & & & & & 0.677 & & & \\
\hline & 17 & & & & & & & 2.023 & & & \\
\hline & 18 & & & & & & & 0.826 & & & \\
\hline \multicolumn{2}{|c|}{ Total Waktu Siklus : } & 14.372 & 16.038 & 17.511 & 11.561 & 16.219 & 7.795 & 16.857 & 15.180 & 12.262 & 127.794 \\
\hline \multicolumn{2}{|c|}{ Nama Stasiun : } & $\begin{array}{l}\text { Main Coil } \\
\text { Winding }\end{array}$ & $\begin{array}{l}\text { Sub Coil } \\
\text { Winding }\end{array}$ & $\begin{array}{c}\text { Coil } \\
\text { Insert }\end{array}$ & $\begin{array}{c}\text { Forming } \\
1\end{array}$ & Lacing & $\begin{array}{l}\text { Caulking- } \\
\text { Dipping }\end{array}$ & $\begin{array}{l}\text { Heating } \\
\text { Air Dryer }\end{array}$ & $\begin{array}{l}\text { Binding- } \\
\text { Forming } 2\end{array}$ & Inspection & \\
\hline \multicolumn{2}{|l|}{ Efisiensi Lini : } & $82.07 \%$ & $91.58 \%$ & $100.00 \%$ & $66.02 \%$ & $92.62 \%$ & $44.51 \%$ & $96.26 \%$ & $86.69 \%$ & $70.02 \%$ & $81.09 \%$ \\
\hline
\end{tabular}

Berdasarkan Tabel 3, terlihat bahwa actual tact time sebesar 17,511 detik, nilai efisiensi stasiun kerja yang variatif, serta efisiensi lini sebesar $81,09 \%$.

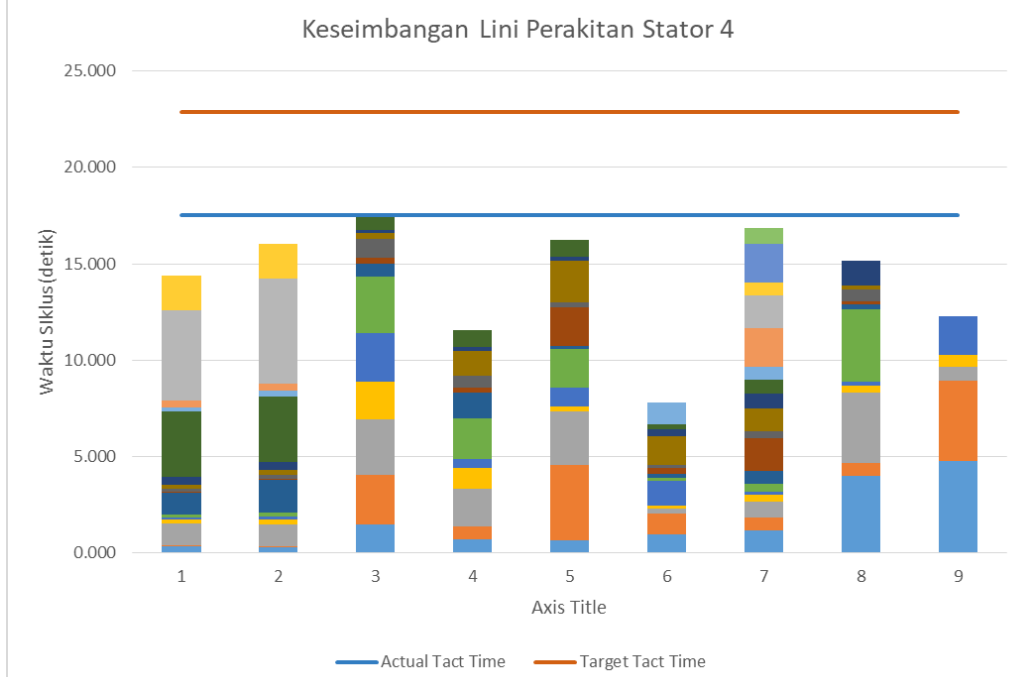

Tingkat keseimbangan lini Perakitan Stator 4 setelah perbaikan diperjelas pada Gambar 6 .

Gambar 6. Grafik Keseimbangan Lini Perakitan Stator 4 Setelah Perbaikan

Berdasarkan Gambar 6, ditunjukkan kondisi keseimbangan lini Perakitan Stator 4 setelah dilakukan perbaikan menjadi lebih seimbang.

\section{Simpulan}

Berdasarkan tahapan perbaikan proses produksi yang telah dilakukan maka usulan perbaikan meliputi perbaikan metode kerja menggunakan ECRS based line balancing pada stasiun kerja 7 (Heating Air Dryer) sampai dengan stasiun terakhir dan berkurangnya tenaga kerja akibat penghilangan stasiun kerja 8 (Insulation Tube). Perbaikan tersebut menyebabkan perubahan pada layout lini Perakitan Stator 4 dan layout stasiun kerja 7 (Heating Air Dryer). Dampak dari perbaikan tersebut adalah peningkatan efisiensi lini Perakitan Stator 4. Nilai efisiensi lini sebelum perbaikan sebesar 74,72\% sedangkan nilai efisiensi lini setelah perbaikan sebesar $81,09 \%$. Namun pada penelitian ini pertimbangan kecepatan conveyor dari stasiun awal ke stasiun tujuan belum dipertimbangkan dan penerapan ECRS based line balancing terbatas pada stasiun kerja 7 (Heating Air Dryer) sampai dengan stasiun kerja Inspection. Sehingga pada penelitian berikutnya dapat mempertimbangkan faktor kecepatan conveyor dalam perancangan layout lini perakitan serta melibatkan 
keseluruhan stasiun kerja dalam perbaikan proses produksi. Selain itu, penerapan otomasi dapat dilakukan pada penelitian ke depan sebagai upaya perbaikan proses produksi. Hal ini dikarenakan faktor pemesinan merupakan salah satu elemen penentu kualitas proses produksi.

\section{Ucapan Terima Kasih}

Ucapan terima kasih diberikan kepada PT. XYZ yang telah memberikan kesempatan kepada penulis untuk melakukan penelitian.

\section{Daftar Pustaka}

Amran, T.G. dan Wibowo, N.C. (2018). Perbaikan Proses Produksi Sistem Pengereman Kendaraan Bermotor dengan Metode ECRS-Base Line Balancing. Prosiding Seminar Nasional Pakar, hal. 193-204. (Surakarta, 24 Maret 2019).

Andriani, D.P. (2017). Penentuan Waktu dan Output Baku Pada Proses Produksi Tube Lamp dengan Methods Time Measurement, Vol. 21, No. 3, [online] https://www.neliti.com/id/publications/ 197007/penentuan-waktu-dan-output-baku-pada-proses-produksi-tube-lamp-dengan-methods-ti (Diakses 24 Maret 2019).

Gaspersz, V. (2004). Operation Planning And Inventory Control. PT Gramedia Pustaka Utama, Jakarta. Marfuah, U., dan Alfiat, C.N. (2014). Analisis Kebutuhan Man Power dan Line Balancing Jalur Supply Body 3 D01N PT. Astra Daihatsu Motor Karawang Assembly Plant (KAP), Vol. 1, No. 1, [online] https://jurnal.umj.ac.id/index.php/jisi/article/view/925 (Diakses 24 Maret 2019).

Nabi, F., Mahmud, R., Islam, M. Md. (2015). Improving Sewing Section Efficiency through Utilization of Worker Capacity by Time Study Technique, Vol. 4, No. 1, [online] http://article.sapub.org/ 10.5923.j.textile.20150401.01.html (Diakses 8 Mei 2019).

Ongkunaruk, P. dan Wongsatit, W. (2014). An ECRS-based line balancing concept: a case study of a frozen chicken producer, Vol. 20, No. 5, [online] https://www.emerald.com/insight/content/ doi/10.1108/BPMJ-05-2013-0063/full/html (Diakses 24 Maret 2019).

Suhardi, B., Anisa, N., Laksono, P.W. (2019). Minimizing waste using lean manufacturing and ECRS principle in Indonesian furniture industry, [online] https://www.researchgate.net/publication/ 330348401_Minimizing_waste_using_lean_manufacturing_and_ECRS_principle_in_Indonesian _furniture_industry (Diakses 22 Juli 2019). 